\title{
AntiCD3Fv fused to human interleukin-3 deletion variant redirected $T$ cells against human acute myeloid leukemic stem cells
}

\author{
Dongmei Fan ${ }^{1 \dagger}$, Zhenzhen $\mathrm{Li}^{1+}$, Xiaolong Zhang ${ }^{1}$, Yuqi Yang ${ }^{2}$, Xiangfei Yuan ${ }^{1}$, Xiuli Zhang ${ }^{1}$, Ming Yang ${ }^{{ }^{*}}$, \\ Yizhi Zhang ${ }^{3^{*}}$ and Dongsheng Xiong ${ }^{1^{*}}$
}

\begin{abstract}
Background: Leukemic stem cells (LSCS) are frequently seen as a cause of treatment failure and relapse in patients with acute myeloid leukemia (AML). Thus, successful new therapeutic strategies for the treatment of AML should aim at eradicating LSCs. The identification of targets on the cell surface of LSCs is getting more and more attention. Among these, CD123, also known as the interleukin-3 (IL3)-receptor a chain, has been identified as a potential immunotherapeutic target due to its overexpression on LSCs in AML as well as on AML blasts, rather than normal hematopoietic stem cells.
\end{abstract}

Methods: We constructed a CD123-targeted fusion protein antiCD3Fv- $\Delta \mathrm{IL} 3$, with one binding site for $\mathrm{T}$ cell antigen receptor (TCRCD3) and the other for CD123, by recombinant gene-engineering technology. Cysteine residues were introduced into the $V$ domains of the antiCD3Fv segment to enhance its stability by locking the two chains of Fv together with disulfide covalent bonds. The stability and cytotoxicity of the two fusion proteins were detected in vitro and in vivo.

Results: Both fusion proteins were produced and purified from Escherichia coli 16C9 cells with excellent yields in fully active forms. High-binding capability was observed between these two fusion proteins and human IL3R, leading to the specific lysis of CD123-expressing cell lines KG1a; also, mononuclear cells from primary AML patients were inhibited in a colony forming assay in vitro, presumably by redirecting T lymphocytes in vitro. In addition, they displayed an antileukemic activity against KG1a xenografts in non-obese diabetic/severe combined immunodeficient (NOD/SCID) mice, especially disulfide-stabilized (ds)-antiCD3Fv- $\Delta \mathrm{IL} 3$ for its improved stability.

Conclusions: These results suggest that both fusion proteins display the antileukemic activity against CD123-expressing cell lines as well as leukemic progenitors in vitro and in vivo, especially ds-antiCD3Fv- $\Delta \mathrm{LL} 3$. They could be the promising candidates for future immunotherapy of AML.

Keywords: AntiCD3Fv, CD123, Fusion proteins, Leukemic stem cells, T cell

\section{Background}

Acute myeloid leukemia (AML) is characterized as the rapid proliferation of immature myeloid cells in the bone marrow, resulting in dysfunctional hematopoiesis [1]. Although most patients can achieve an initial complete

\footnotetext{
*Correspondence: my1970@sina.com; yz5168813@sohu.com; dsxiong@ ihcams.ac.cn

${ }^{\dagger}$ Equal contributors

'State Key Laboratory of Experimental Hematology, Institute of Hematology \& Hospital of Blood Diseases, Chinese Academy of Medical Sciences and Peking Union Medical College, Tianjin 300020, People's Republic of China

${ }^{3}$ Central Hospital of Karamay, Karamay, Xinjiang 834000, China

Full list of author information is available at the end of the article
}

remission with standard induction chemotherapy, the majority of them eventually relapse and become resistant to cytotoxic chemotherapy [2]. Leukemic stem cells (LSCs) are a common cause of the treatment failure and the relapse in these patients [3-5], and moreover, their gene signature are significantly associated with the prognosis of human AML [6]. Therefore, development of novel therapeutics that can selectively target LSCs is crucial. Recently, many researchers have identified several AML-associated cell surface phenotypic markers that can be used as future therapeutic targets [7]. Among them, CD123, also known as the interleukin-3 (IL3) receptor $\alpha$ 
chain, has received a considerable amount of interest, due to its overexpression in LSCs in AML rather than normal hematopoietic stem cells $[7,8]$. Pre-clinical studies using a monoclonal antibody targeting CD123 (7G3) or diphtheria toxin fused to interleukin-3 (DT388IL3) for the treatment of AML have demonstrated promising antileukemic activity [9-11].

A more potentially efficient approach for cancer prevention and treatment is to manipulate the immune system of patients toward cancers cells $[12,13]$. As we know, $\mathrm{T}$ cells play a pivotal role in tumor immunity by directly eliminating tumor cells through formation of synapses of cytotoxic $\mathrm{T}$ cell tumor cells [14]. However, $\mathrm{T}$ cells usually cannot effectively identify tumor cells or become anergic because of the complexity of the T cell recognition mechanism [15]. In the past two decades, scientists have already taken advantage of $\mathrm{T}$ cell potency in cancer therapy by redirecting their specificity toward cell surface tumor-associated antigens. For example, bispecific antibodies, by simultaneously recognizing target antigen on the surface of cancer cells and an activating receptor on the surface of an immune effector cell, offer an opportunity to redirect immune effector cells to kill cancer cells. The other approach is the generation of chimeric antigen receptors (CAR) by fusing extracellular antibodies to intracellular-signaling domains. And then, the CAR-engineered $\mathrm{T}$ cells are able to specifically kill tumor cells in a major histocompatibility complex (MHC)-independent way. The above two approaches, both showing promising clinical results, are recognized as the most effective immuno-biological therapeutics for tumors [16]. Recently, Kuo et al. described a bispecific singlechain $\mathrm{Fv}$ (scFv) immunofusion or BIf to target CD123+ leukemia in vitro that contains an antiCD123 scFv fused at the N-terminus of human IgG1 hinge- $\mathrm{C}_{\mathrm{H}} 2-\mathrm{C}_{\mathrm{H}} 3$ and an antiCD3 scFv fused at C-terminus [17]. While, Mardiros et al. developed two CD123 CAR-redirected T cells mediated potent effector activities against CD123+ cell lines as well as primary AML patient samples in vitro and in vivo [18]. Similarly, Sarah Tettamanti et al. have constructed CD123-specific CARs that can strongly enhance antiAML CIK functions [19]. All these works proved the effectiveness of the CD123-retargeted T cell therapy.

IL3 is a cytokine that promotes the proliferation and differentiation of multipotential and committed myeloid and lymphoid progenitors [20]. The IL3 receptor is a heterodimeric structure composed of $\alpha$ and $\beta$ subunits. The $\alpha$ chain (CD123) directly binds IL3, and the $\beta$ subunit is used to conduct signals [21]. The ligand-receptor-binding activity is considered to be very potent. To further increase the stability of the ligand-receptor binding, combinatorial mutagenesis studies by several laboratories showed that deletion of eight $\mathrm{C}$-terminal amino acid residues from IL3 ( $\triangle 125-133)$ or the variant K116W resulted in even higher affinity interactions with IL3R and greater cytotoxicity against human leukemic stem cells [22-25].

Based on these previous findings, here we constructed a similar fusion protein antiCD3Fv- $\triangle \mathrm{IL} 3$ (with the Cterminal eight amino acids of IL3 deleted, $\Delta 125-133$ ), just as bispecific antibodies, that is theoretically capable of recruiting a polyclonal $\mathrm{T}$ cell against LSCs that express $\mathrm{CD} 123$, with one of its arms to the common $\mathrm{T}$ cell signaling protein $\mathrm{CD} 3$ and the other to the tumorassociated antigen CD123 on the target LSCs. Moreover, to enhance the stability of the fusion protein, a disulfidestabilized format (ds-antiCD3Fv- $\triangle \mathrm{IL} 3$ ) of this fusion protein was generated by locking the two chains of $\mathrm{Fv}$ together with disulfide covalent bonds. High-binding capability was observed between these two fusion proteins and human IL3R, leading to the specific lysis of CD123-expressing cell lines KG1a; also, mononuclear cells from primary AML patients were inhibited in a colony-forming assay in vitro, presumably by redirecting T lymphocytes in vitro. In vivo, they displayed an antileukemic activity against KG1a xenografts in non-obese diabetic/severe combined immunodeficient (NOD/SCID) mice. And the ds-antiCD3Fv- $\triangle \mathrm{IL} 3$ demonstrated an even better performance due to its higher stability. Two advantages make the fusion proteins more effective: first, they were composed of antiCD3Fv and human recombinant IL3, resulting in low immunogenicity; second, $\triangle \mathrm{IL} 3$, the ligand of CD123, was employed, demonstrating a better binding activity than the antigen-antibody binding.

\section{Results}

\section{Construction and expression of fusion proteins} antiCD3Fv- $\triangle \mathrm{IL} 3$ and ds-antiCD3Fv- $\triangle \mathrm{IL} 3$

The nucleotide sequences encoding the fusion proteins were verified by DNA sequencing. The last eight amino acids at the C-terminal of IL3 were entirely deleted. In addition, the Ser-100 of antiCD3 $\mathrm{V}_{\mathrm{L}}$ and Gly-44 of antiCD3 $\mathrm{V}_{\mathrm{H}}$ were successfully replaced by cysteines (Figure 1B). The fusion proteins were expressed by cosecretion of the two polypeptide chains (antiCD3 $\mathrm{V}_{\mathrm{L}}-\triangle \mathrm{IL} 3$ or antiCD3* $\mathrm{V}_{\mathrm{L}}-\Delta \mathrm{IL} 3$ and antiCD3 $\mathrm{V}_{\mathrm{H}^{-}} \triangle \mathrm{IL} 3-\mathrm{His}$ or antiCD3* $\left.\mathrm{V}_{\mathrm{H}^{-}}-\Delta \mathrm{IL} 3-\mathrm{His}\right)$ from Escherichia coli 16C9 cells as periplasmic native proteins (Figure $1 \mathrm{~A}, \mathrm{~B}$ ). Then, antiCD $3 \mathrm{~V}_{\mathrm{L}^{-}} \triangle \mathrm{IL} 3$ and antiCD3 $\mathrm{V}_{\mathrm{H}^{-}}-\triangle \mathrm{IL} 3-\mathrm{His}$ were folded to form fusion protein antiCD3Fv- $\triangle \mathrm{IL} 3$ depending on the intermolecular force (Figure 1C) whereas the two cysteine-mutated polypeptide chains antiCD3* $\mathrm{V}_{\mathrm{L}}-\triangle \mathrm{IL} 3$ and antiCD3* $\mathrm{V}_{\mathrm{H}^{-}} \Delta \mathrm{IL} 3-\mathrm{His}$ formed fusion protein ds-antiCD3Fv- $\triangle \mathrm{IL} 3$ relying on the disulfide bonds in the periplasmic space (Figure 1D). The fusion proteins were released from the periplasmic space of $E$. coli by osmotic shock and purified by $6 \times$ His-tag affinity chromatography. The yields of purified fusion proteins ranged from 1 to $2 \mathrm{mg} / \mathrm{L}$ of culture medium. 


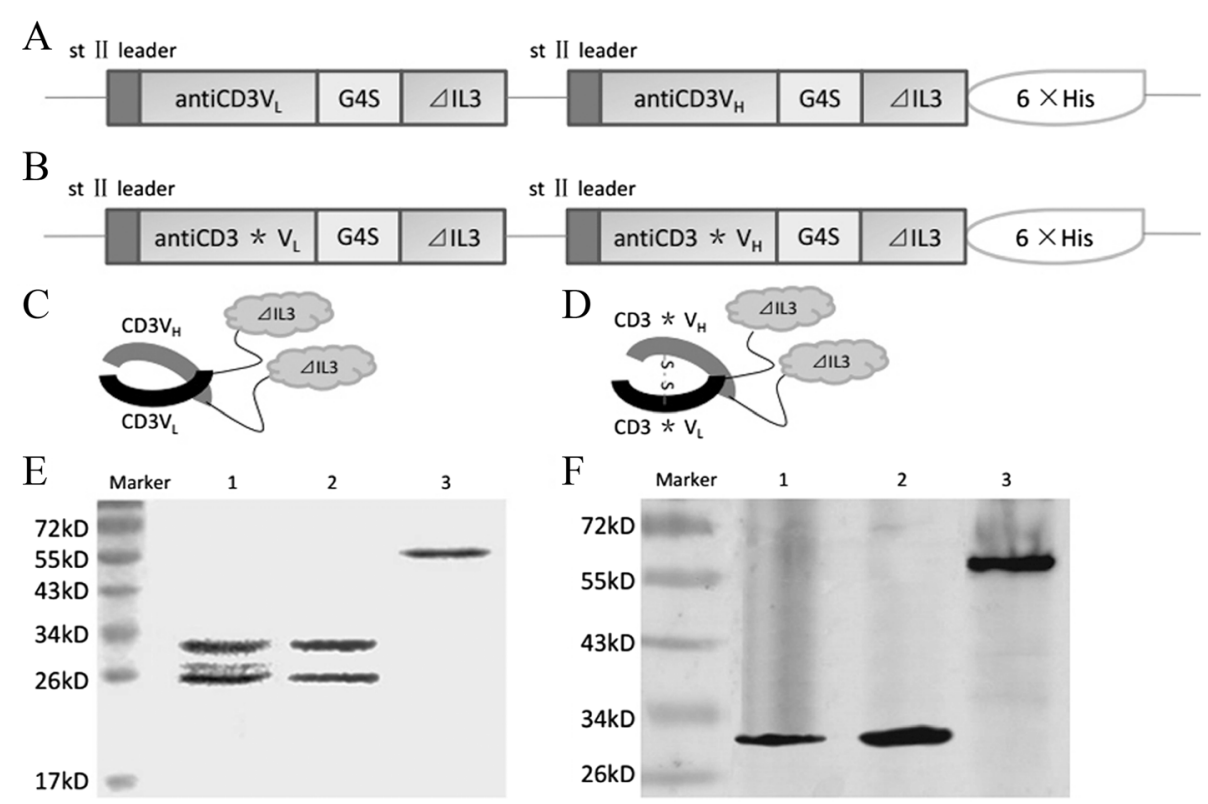

Figure 1 Expression and purification of the fusion proteins antiCD3Fv- $\triangle \mathrm{IL} 3$ and the ds-antiCD3Fv- $\Delta \mathrm{IL} 3$. Schematic of the expression plasmid for (A) antiCD3Fv- $\Delta \mathrm{LL} 3$ and (B) ds-antiCD3Fv- $\Delta \mathrm{LL}$, and structure of the fusion proteins for (C) antiCD3Fv- $\Delta \mathrm{lL} 3$ and (D) ds-antiCD3Fv- $\Delta \mathrm{IL} 3$. Note: the drawing is not to scale; asterisk (*) indicates the site of the disulfide bond. The fusion proteins were expressed in E. coli, purified by affinity chromatography, and analyzed by SDS-PAGE and immunoblotting. (E) Colloidal staining of a SDS-PAGE gel. Lane 1: antiCD3Fv- $\triangle \mathrm{IL} 3$ in non-reducing loading buffer; lane 2: ds-antiCD3Fv- $\Delta \mathrm{L}$ 3 3 in reducing loading buffer; lane 3: ds-antiCD3Fv- $\Delta \mathrm{LL} 3$ in non-reducing loading buffer. (F) Immunoblot analysis of the SDS-PAGE gel with an anti-His-tag antibody. Lane 1: antiCD3Fv- $\Delta \mathrm{IL} 3$ in non-reducing loading buffer; lane 2: ds-antiCD3Fv- $\Delta \mathrm{IL} 3$ in reducing loading buffer; lane 3: ds-antiCD3Fv- $\triangle \mathrm{LL} 3$ in non-reducing loading buffer.

The purified fusion proteins were analyzed by SDSPAGE and Western blot. The fusion protein antiCD3Fv$\triangle \mathrm{IL} 3$ was resolved under electrophoretic conditions and detected as two bands of approximately 30 and $27 \mathrm{kD}$, corresponding to the two polypeptide chains of antiCD3 $\mathrm{V}_{\mathrm{H}^{-}}$ $\triangle \mathrm{IL} 3$ and antiCD3V $\mathrm{L}_{\mathrm{L}}-\Delta \mathrm{IL} 3$, respectively, as anticipated (Figure 1E). Under reducing conditions, the fusion protein ds-antiCD3Fv- $\triangle \mathrm{IL} 3$ was resolved into two proteins bands consistent with those of antiCD3Fv- $\triangle \mathrm{IL} 3$. However, under non-reducing conditions, the fusion protein ds-antiCD3Fv$\triangle \mathrm{IL} 3$ was detected as one band at approximately $57 \mathrm{kD}$ (Figure 1E). Western blot analysis using an anti-His-tag antibody validated the existence of the His-tag-containing fragment and confirmed that the two polypeptide chains of antiCD3* $\mathrm{V}_{\mathrm{L}^{-}} \triangle \mathrm{IL} 3$ and antiCD3* $\mathrm{V}_{\mathrm{H}^{-}} \Delta \mathrm{IL} 3$ were linked by the disulfide bond (Figure 1F).

\section{Dual specificity of the fusion proteins antiCD3Fv- $\triangle \mathrm{IL} 3$ and ds-antiCD $3 F v-\triangle I L 3$}

Both antiCD3Fv- $\triangle \mathrm{IL} 3$ and ds-antiCD3Fv- $\triangle \mathrm{IL} 3$ bind to CD123-positive KG1a cells and CD3-positive Jurkat cells with similar efficiency as their parental monoclonal antibodies CD123 and HIT3a to the respective target cells (Figure 2A,B,E,F). Furthermore, both fusion proteins were able to partly reduce the binding efficiency of the parental monoclonal antibodies HIT3a and CD123 McAb to Jurkat and KG1a, respectively, in a competitive binding assay (Figure 2C,D,G,H). No significant decrease in binding activity of ds-antiCD3Fv- $\triangle \mathrm{IL} 3$ fusion protein was detected compared to the parental fusion protein antiCD3Fv- $\triangle \mathrm{IL} 3$.

\section{Stability of fusion proteins antiCD3Fv- $\triangle \mathrm{IL} 3$ and ds-antiCD3Fv- $\triangle \mathrm{IL} 3$ in vitro}

The stability of the fusion proteins in vitro was determined by analysis of their binding to target cells after incubation in PBS containing $0.2 \%(w / v)$ human serum albumin (HSA) at $37^{\circ} \mathrm{C}$ for several hours. The results showed that the binding capacity of the fusion proteins antiCD3Fv- $\triangle \mathrm{IL} 3$ was reduced by nearly $50 \%$ after incubation for $6 \mathrm{~h}$ and $80 \%$ for $72 \mathrm{~h}$, while the binding capacity of the ds-antiCD3Fv- $\triangle \mathrm{IL} 3$ remained more than $90 \%$ after $72 \mathrm{~h}$ (Figure $3 \mathrm{~A}, \mathrm{~B})$.

Tumor cell lysis mediated by fusion proteins antiCD3Fv- $\Delta$ IL3 and ds-antiCD3Fv- $\triangle \mathrm{lL} 3$

A non-radioactive cytotoxicity assay was performed to determine the ability of the fusion proteins antiCD3Fv- $\triangle \mathrm{IL} 3$ and ds-antiCD3Fv- $\triangle \mathrm{IL} 3$ to induce lysis of CD123+ tumor cells in the presence of pre-activated human $\mathrm{T}$ cells. The fusion proteins antiCD3Fv- $\triangle \mathrm{IL} 3$ and ds-antiCD3Fv- $\triangle \mathrm{IL} 3$ appeared to be potent in retargeting $\mathrm{T}$ cell lysis of the CD123-positive KG1a cells (Figure 4A,B,C), whereas CD123-negative cells THP1 and NB4 were not lysed 

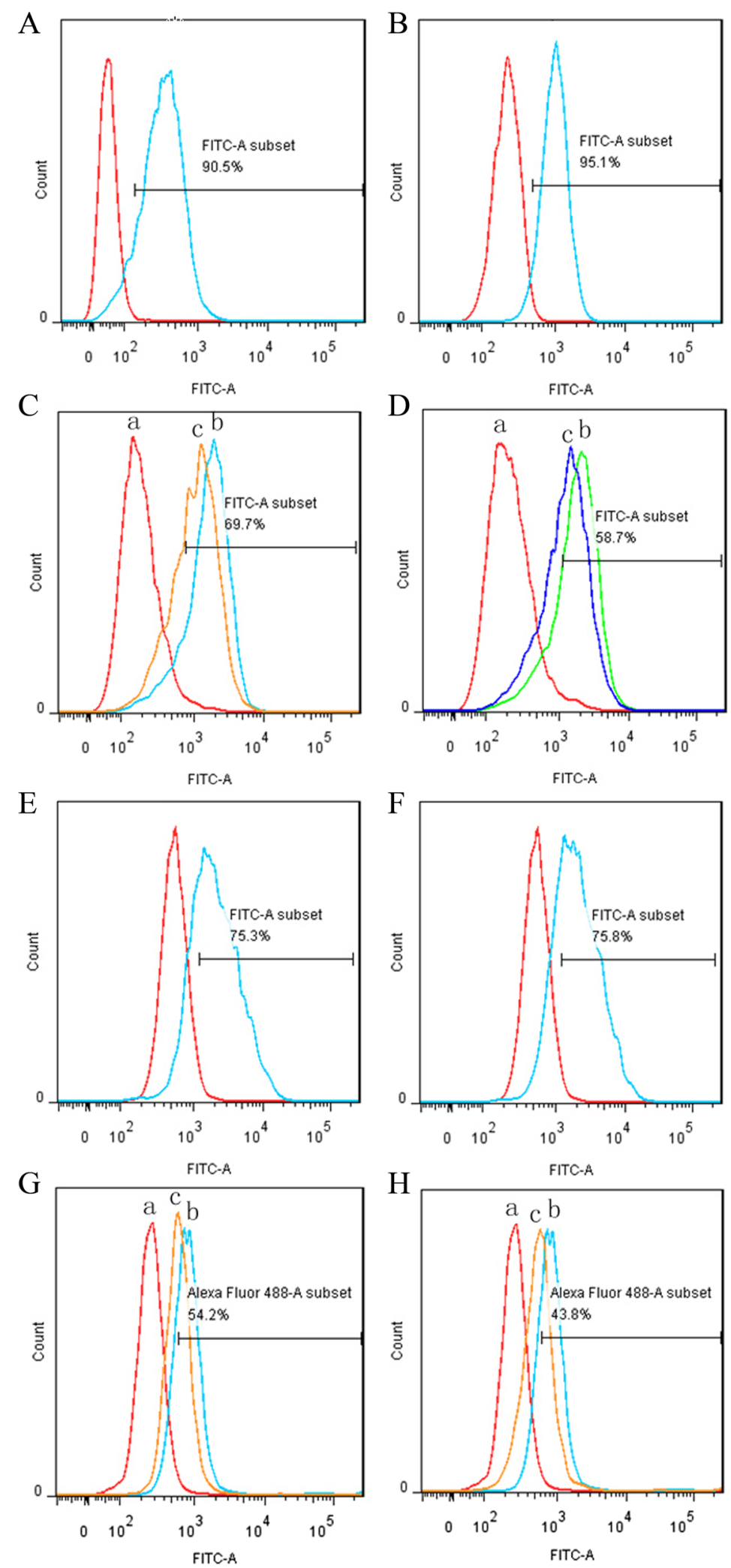

Figure $\mathbf{2}$ (See legend on next page.) 
(See figure on previous page.)

Figure 2 Analysis of specific binding of fusion proteins antiCD3Fv- $\triangle \mathrm{IL} 3$ and ds-antiCD3Fv- $\triangle \mathrm{IL} 3$ to Jurkat and KG1a, as well as the competitive binding activity with monoclonal antibody HIT3a or CD123. (A, B) Jurkat cells were incubated with fusion proteins (A) antiCD3Fv- $\triangle \mathrm{LL} 3$ or (B) ds-antiCD3Fv- $\Delta \mathrm{L}$ 3. (E-F) KG1a cells were incubated with (E) antiCD3Fv- $\Delta \mathrm{LL} 3$ or (F) ds-antiCD3Fv- $\Delta \mathrm{L}$ 3. Note: the gate represented the positive rate of binding of fusion proteins. In the competitive binding assay, (C, D) Jurkat cells were first incubated with ((C): c) antiCD3Fv- $\Delta \| \mathrm{ll} 3$ or ((D): c) ds-antiCD3Fv- $\Delta \| \mathrm{L} 3$ and HIT3a. (G, H) KG1a cells were first incubated with ((G): c) antiCD3Fv- $\Delta \mathrm{LL} 3$ or $((\mathbf{H})$ : c) ds-antiCD3Fv- $\Delta \mathrm{L}$ 3 and mAb CD123, then incubated with an FITC-conjugated antimouse lgG. Control groups only reacted with (a.) PBS and (b.) parent mAb lgG. Note: the gate represented the binding rate of the line of $\mathrm{c}$ with monoclonal antibody HIT3a or CD123.

under the same conditions (Figure 4D,E). Correspondingly, the ratio of apoptotic cells in the group of antiCD3Fv- $\triangle \mathrm{IL} 3(65.633 \% \pm 3.807 \%)$ and ds-antiCD3Fv$\triangle \mathrm{IL} 3(67.733 \% \pm 3.821 \%)$ were increased when combined with pre-activated human T cells (Figure 4F,G). Additional movie files show this process of target cell lysis in more detail (see Additional file 1: Movie 1, Additional file 2: Movie 2, Additional file 3: Figure S1, and Additional file 4: Figure S2). Lysis of target cells mediated by the fusion
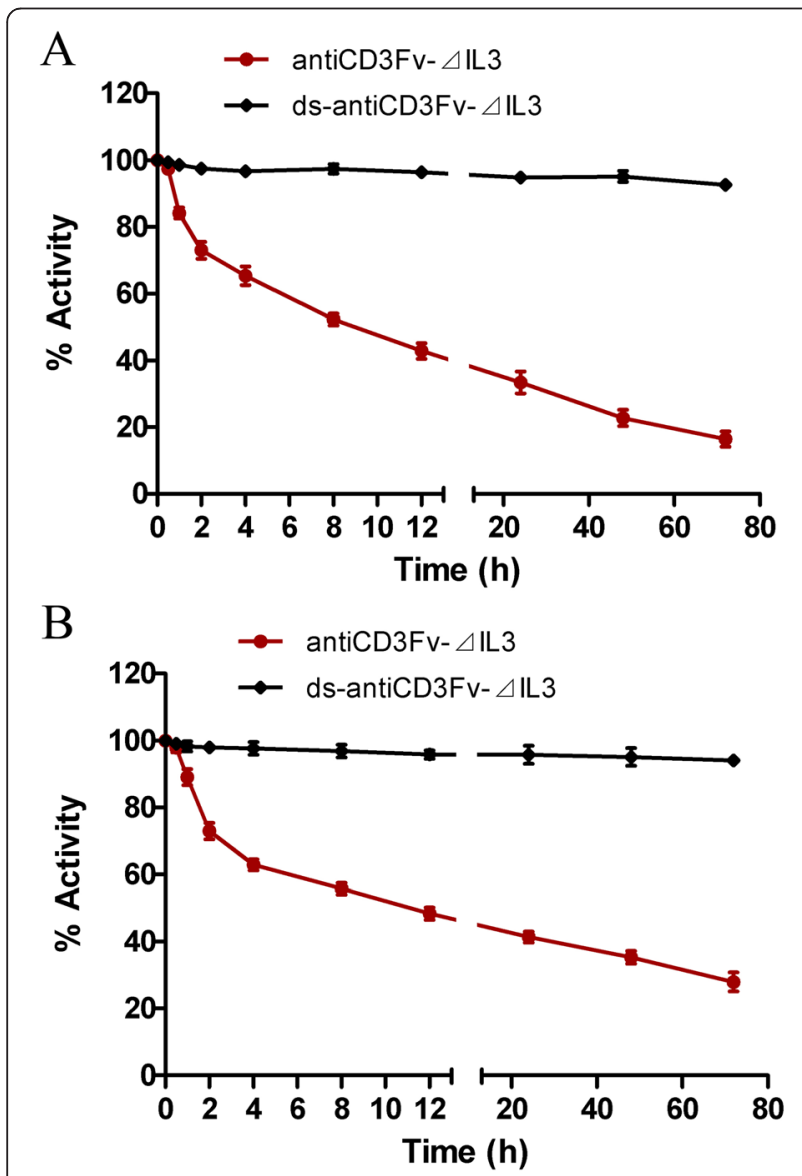

Figure 3 Comparison of the stability of fusion proteins antiCD3Fv- $\triangle \mathrm{IL} 3$ and ds-antiCD3Fv- $\triangle \mathrm{IL} 3$ in vitro. The stability was determined by testing binding activity of fusion proteins to (A) CD3-positive Jurkat cells or (B) CD123-positive KGla cells after incubation in $0.2 \% \mathrm{HSA}$ at $37^{\circ} \mathrm{C}$ for a prolonged time period. Data were normalized to $t_{0}$ (initial time), which was set at $100 \%$. The data shown represent the averages of three independent experiments. protein or ds fusion protein increased in a dose-dependent manner: increasing either the concentration of fusion proteins or the ratio of effector to target cells resulted in enhanced target cell cytotoxicity (Figure 4A,B). The cytotoxic activity was not enhanced when an equal amount of the antiCD3/antiCD19 diabody was added, because CD19 was not expressed on the KG1a cells (Figure 4C). There was no statistical difference between the parental fusion protein and the ds fusion protein $(500 \mathrm{ng} / \mathrm{mL})$ in mediating the lysis of KG1a cells at various E:T ratios (Figure 4C).

\section{Cytotoxicity of $T$ cells mediated by the fusion proteins against AML leukemic progenitors}

The peripheral blood mononuclear cells from six newly diagnosed AML patients were incubated in serum-free IMDM for $24 \mathrm{~h}$ in the presence or absence of different fusion proteins combined with pre-activated $\mathrm{T}$ cells. Treated and untreated cells were then plated in AMLcolony-forming cell (CFC) assays to evaluate the relative cytotoxicity of $\mathrm{T}$ cells mediated by the fusion proteins against these leukemic progenitors. AML-CFCs were detected in control (including PBS-treated or fusion proteins without pre-activated $\mathrm{T}$ cells) cultures of all six AML samples, ranging from 112 to $490 \mathrm{AML}-\mathrm{CFCs} / 10^{4}$ cells (Figure 5A,B,C,D). After 24-h exposure to fusion proteins with pre-activated $\mathrm{T}$ cells, the mean percentages of kill of AML-CFCs were $53.3 \%$ and $52.8 \%$, respectively, for antiCD3Fv- $\triangle \mathrm{IL} 3$ and ds-antiCD3Fv- $\triangle \mathrm{IL} 3$, (range, $33.9 \% \sim 63.4 \%$ ) (Figure 5A,E,F). There was no statistical difference between the parental fusion protein and the ds fusion protein $(500 \mathrm{ng} / \mathrm{mL})$ in mediating the inhibition of colony formation of AML leukemic progenitors in vitro (Figure 5A). These findings indicate that the two fusion proteins can preferentially retarget $\mathrm{T}$ cells to AML progenitor cells.

Inhibition of growth of human KG1a xenografts in vivo We established a NOD/SCID mouse model bearing the human AML progenitor cell line KG1a to determine whether the fusion proteins also had an antitumor activity in vivo. The pathological finding showed KG1a tumor cells were in diffuse and intensive distribution, which indicated the subcutaneous KG1a xenotransplanted model was established successfully (Figure 6A). The expression level of CD123 on the surface of KG1a xenografts 


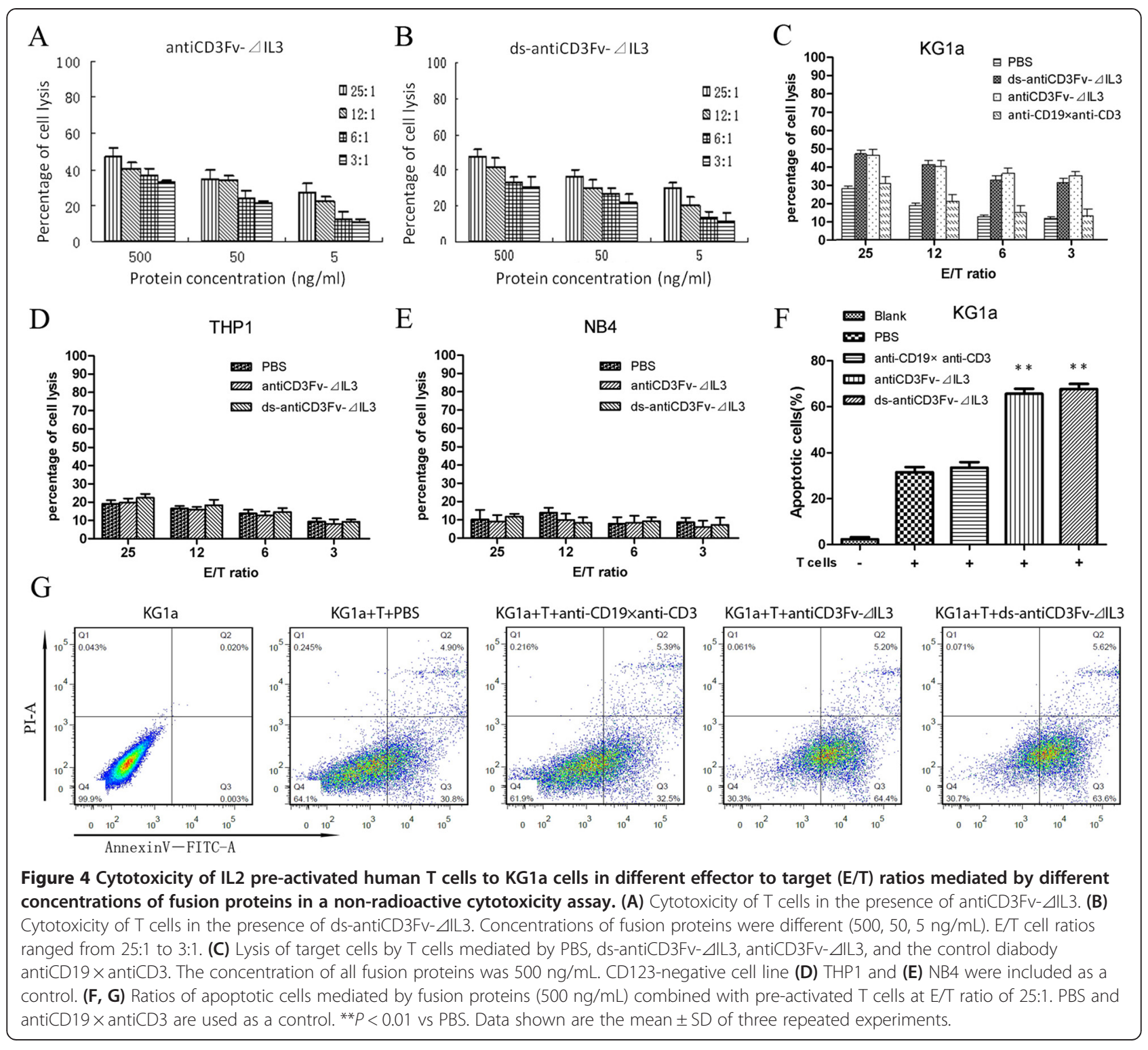

$(70.620 \% \pm 5.023 \%)$ was slightly reduced compared with KG1a cell line $(77.875 \% \pm 3.090 \%)$ (Figure 6B). Two doses (50 and $100 \mu \mathrm{g} /$ mouse) of the fusion proteins were chosen to evaluate their ability to inhibit tumor growth in NOD/SCID mice. Animals were sacrificed when the tumors had grown to approximately $4,000 \mathrm{~mm}^{3}$ in size. As shown in Figure $6 \mathrm{C}$, compared to the mice in the control group (untreated), the mice treated with different dosages of fusion proteins antiCD3Fv- $\triangle \mathrm{IL} 3$ or ds-antiCD3Fv$\triangle \mathrm{IL} 3$ combined with pre-activated T lymphocytes showed a significant dose-related tumor regression. Furthermore, the ds fusion protein had a better antitumor activity than the parental fusion protein, when equivalent doses of ds fusion protein and the parent fusion protein were compared. The ability of tumor regression still exceeded its parental fusion protein slightly, even with half dose of the ds fusion protein (Figure 6C).

\section{Discussion}

Although current treatment regimens for AML can achieve a complete remission, most patients will ultimately relapse and die from the disease or complications associated with the treatment [2], emphasizing the unmet medical need for novel therapeutics that are more effective and durable. Recent advances in AML-targeting immunotherapies including dendritic cell vaccines, adoptive $\mathrm{T}$ cell therapy, and antigen-specific cytotoxic $\mathrm{T}$ lymphocytes open the possibilities for eradicating minimal residual diseases which contain chemoresistant LSCs after chemotherapy [26]. To this end, we chose the 


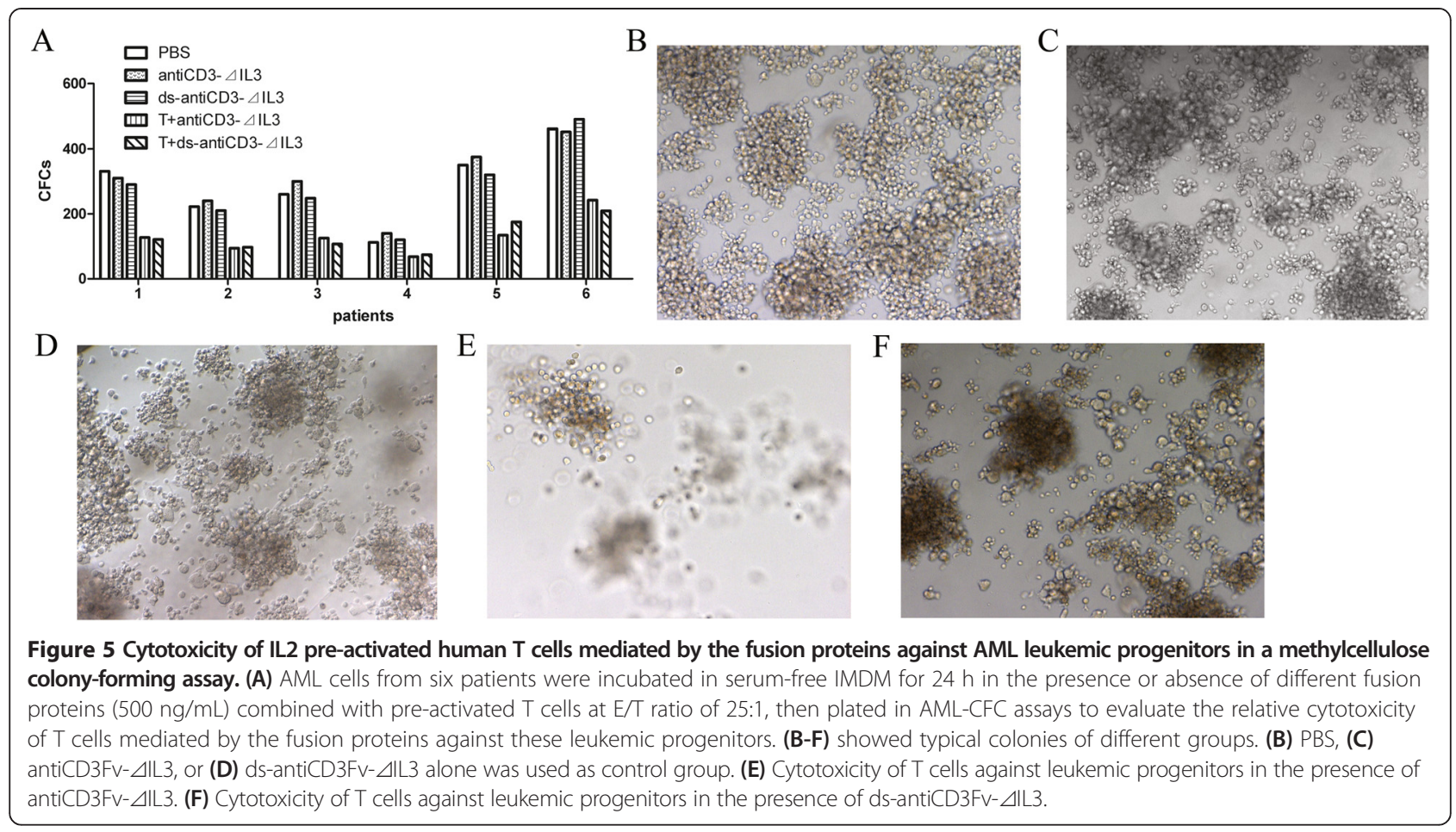

antigen CD123 out of several cell surface antigens preferentially expressed on AML LSCs compared with normal hematopoietic stem cells, including CD123, CD44, CLL-1, CD47 [7], and T cell immunoglobulin mucin-3 (TIM-3) [27], the rationale of its selection being its overexpression not only by the bulk AML population, but also by LSCs in $75 \%-89 \%$ of AML patients [28-30]. In this study, we aimed to develop a fusion protein antiCD3Fv- $\nabla$ IL3 that would direct $\mathrm{T}$ cell to specifically target CD123+ AML cells just like bispecific antibodies. Since the heavy chain $\left(\mathrm{V}_{\mathrm{H}}\right)$ and the light chain $\left(\mathrm{V}_{\mathrm{L}}\right)$ domains of antiCD3Fv are associated non-covalently, they dissociated relatively easily. To enhance the stability of the fusion protein, we employed disulfide covalent bonds to lock the two chains together as we have done before in the antiPgp $\times$ antiCD3 diabody and the antiCD19 $\times$ antiCD3 diabody, both of which showed a higher antitumor activity in animal models [31,32]. As expected, the disulfidestabilized antiCD3Fv- $\triangle \mathrm{IL} 3$ improved the serum stability by the disulfide cross-linking of the CD3 Fv fragments. The results showed that ds-antiCD3Fv- $\triangle \mathrm{IL} 3$ retained $90 \%$ activity even after 3 days post incubation at $37^{\circ} \mathrm{C}$ in PBS, compared with the parent fusion protein with a $t 1 / 2$ of $6 \mathrm{~h}$ under the same conditions (Figure 3A,B). In addition, the ds-antiCD3Fv- $\triangle \mathrm{IL} 3$ had the same antigenbinding specificity and cytotoxic activity in vitro as the parent fusion protein (Figure 4A,B). Thus, compared with the parent fusion protein, the more stable ds-antiCD3Fv$\triangle \mathrm{IL} 3$ may conceivably penetrate deeper into the tumor and stay longer in the tumor, resulting in a greater antitumor activity in vivo (Figure 6C).

The expression of multiple cell surface tumorassociated antigens on AML cells has been well characterized $[7,26,27]$. In this work, we have engineered fusion proteins to redirect $\mathrm{T}$ cells to target CD123+ AML cells. The CD123 is highly expressed by primary AML cells, as well as LSCs, while displaying limited expression on hematopoietic stem cells and T cells $[7,28,30]$. The LSCs are thought to be spared from chemotherapy and capable of reinitiating the disease. Anne S. Rong et al. have discovered CD123 and hMICL in combination with CD34 and CD117 as a universal marker combination for the detection of minimal residual disease (MRD) of AML in pre-clinical and clinical settings [33]. Thus, therapies targeting CD123 aiming at eradicating LSCs should be the successful novel therapeutic strategy, which can be applied after the standard induction chemotherapy to eliminate MRD and reduce recurrence. As expected, therapies targeting CD123 have showed favorable safety profiles in phase I trials (ClinicalTrials.gov ID\#NCT00401739 and \#NCT00397579). Besides, there are some other AML antigens which may be potential targets. For instance, the epithelial mucin, MUC1, is expressed on primary AML cells and can be recognized by MUC1-specific cytotoxic $\mathrm{T}$ lymphocytes [34]. The CD47 is identified as an adverse prognostic factor and is more highly expressed on AML LSC than their normal counterparts [35]. The TIM-3 antigen is another target 

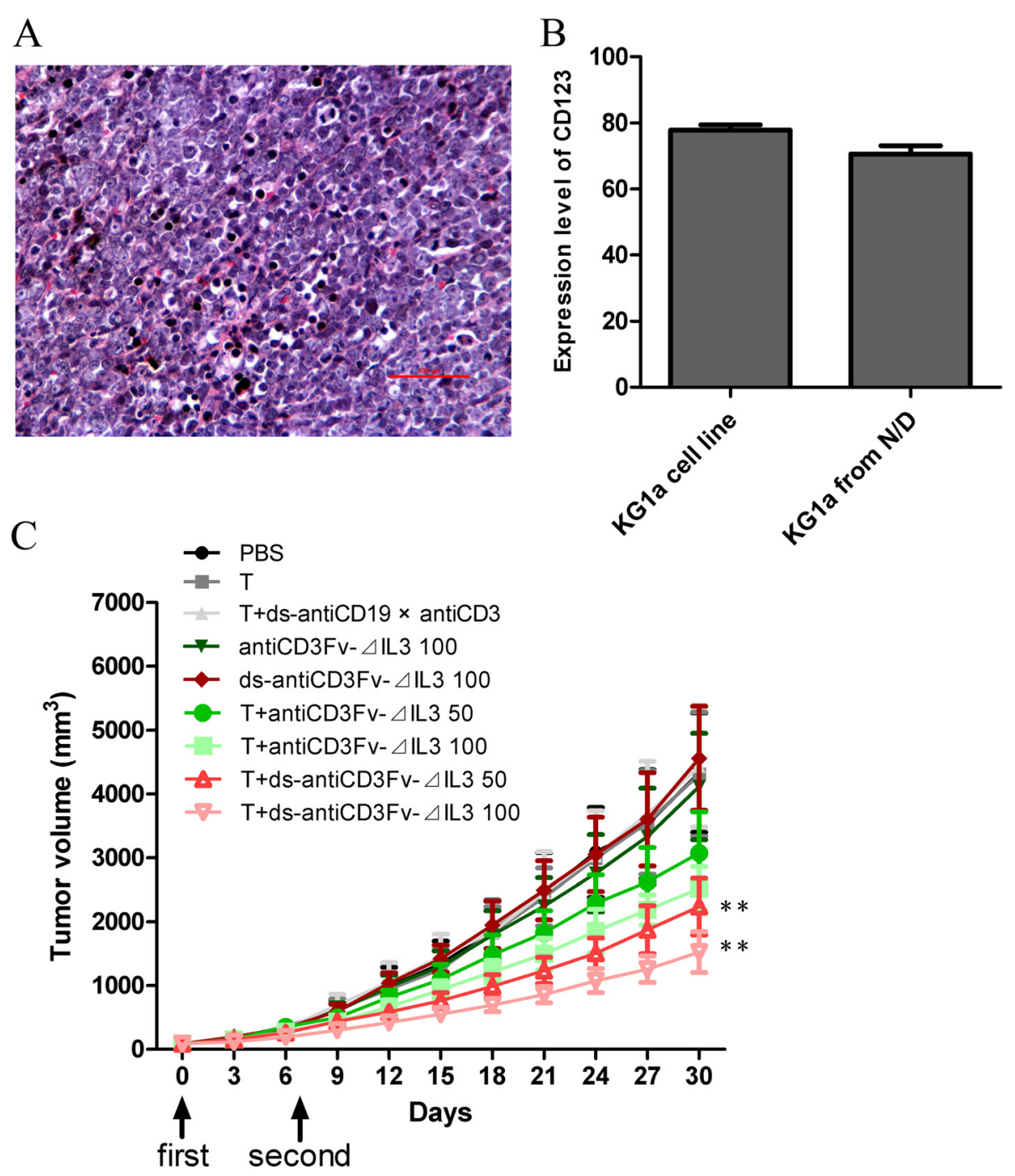

Figure 6 Antitumor effect of fusion proteins antiCD3Fv- $\triangle \mathrm{IL3}$ and ds-antiCD3Fv- $\triangle \mathrm{IL} 3$ in KG1a xenografted NOD/SCID mice. (A) H\&E staining showed the KG1a tumor cells were diffused and in intensive distribution, indicating subcutaneous KG1a xenotransplanted model was established successfully. (B) The expression level of CD123 on the surface of KG1a xenografts and KG1a cell line were analyzed by FACS. (C) A mixture of T cells and fusion proteins antiCD3Fv- $\Delta \mathrm{LL} 3$ or ds-antiCD3Fv- $\Delta \mathrm{lL} 3$ in different concentrations (50 and $100 \mathrm{\mu g} / \mathrm{mouse}$ ) were injected intravenously 6 days later, when the solid tumors reached $80-100 \mathrm{~mm}^{3}$ in size, once per week for 2 weeks. PBS, antiCD3Fv- $\Delta \mathrm{IL} 3, \mathrm{ds}$-antiCD3Fv- $\Delta \mathrm{L}$ 3, and $T$ cells alone, and T cells combined with antiCD19 $\times$ antiCD3 diabody, were used as control groups. The size of the xenografts was measured every 3 days. Error bars indicate SD $(n=5) .{ }^{* *} P<0.01$ vs PBS.

that can be used to selectively kill AML LSCs, but its expression on a subset of $\mathrm{T}$ cells may result in autolysis of $\mathrm{T}$ cells [36], making it a non-ideal target for a T-cellbased therapy.

Anticancer immunity involves both the innate and adaptive immune systems, yet it is generally considered that CD8+ cytotoxic T lymphocytes (CTL) are the most potent antitumor effector cells [37]. But in fact, researches have been acutely aware that tumor cells can develop multiple escape mechanisms, such as a physical barrier avoiding infiltration of effector cells and lower expression level of $\mathrm{MHC}$ as well as secretion of cytokines that indirectly inhibit $\mathrm{T}$ cell proliferation [37]. Therefore, specific reagents for $\mathrm{T}$ cell retargeting have been developed to make $\mathrm{T}$ cells kill tumors more effectively. Among different approaches, the most potent therapeutics are the use of bispecific antibodies and CARs to redirect $\mathrm{T}$ cell specificity toward cell surface tumor-associated antigens. CARs, known as chimeric immune receptors, should be inserted into effector cells, and then, they can redirect effector cell specificity toward cell surface tumor-associated antigens independent of the $\mathrm{T}$ cell receptor (TCR)-defined specificity and in a MHC-independent manner. This technology has shown an excellent efficacy in pre-clinical studies as 
well as clinical trials [38,39]. However, the use of CARs may also be dangerous, such as, the activation of effector cells can be too strong to lead to a cytokine storm and even to death [40]. Therefore, clinical use of CARs is still limited by the complexity of engineering processes and further improvement needs to be done. The efficacy of bispecific antibodies has already been validated in pre-clinical studies and has shown promising results in clinical trials, for example, antiCD19 $\times$ antiCD3 BiTE Ab called blinatumomab in phase II trial (ClinicalTrials.gov ID\#NCT01207388) has shown an $80 \%$ complete molecular response rate and prolonged leukemia-free survival in patients with minimal residual B-lineage acute lymphoblastic leukemia [41]. Besides, there are some other bispecific antibodies under clinical trials, such as antiEpCAM $\times$ antiCD3 for epithelial cancers or gastric cancer in phase II/III trial, antiHER- $2 \times$ antiCD3 for metastatic or advanced breast cancer in phase II trial [16]. To target CD123, Shu-Ru Kuo et al. have engineered a CD123 $\times$ CD3 bispecific scFv immunofusion to target CD123+ LSCs in vitro, which contained an antiCD123 scFv fused at the $\mathrm{N}$-terminus of human IgG1 hinge- $\mathrm{CH} 2-\mathrm{CH} 3$, and an antiCD3 scFv fused at $\mathrm{C}-$ terminus; the molecular weight of $140 \mathrm{kDa}$ would affect their penetration into tumor tissue [17]. Then, in our work, we successfully constructed a smaller fusion protein antiCD3Fv- $\triangle \mathrm{IL} 3$ and its disulfide-stabilized antiCD3Fv$\triangle \mathrm{IL} 3$, both displaying a potent antileukemic activity, especially for the ds-antiCD3Fv- $\triangle \mathrm{IL} 3$ in vivo. Compared with CD123-specific CAR T cells, this approach is less efficient against AML LSCs but more convenient and controllable in the clinical application. To enhance the curative effect of antiCD3Fv- $\triangle \mathrm{IL} 3$, it is possible to develop a multiepitope reagent, because its manner of $\mathrm{T}$ cell activation is dependent on $\mathrm{T}$ cell receptor functional signals which may be defective in cancer patients.

Moreover, due to the overexpression of CD123 (IL3R $\alpha$ ) on AML leukemic stem cells, researchers have exploited drugs that fuse IL3 to efficient toxin or chemotherapeutics to eradicate human AML stem cells. Among these fusion proteins, the DT388IL3 showed cytotoxicity to LSCs in vitro and in vivo with minimal damage to normal tissues $[10,11]$. Currently, phase II clinical trial has been completed. Furthermore, researchers also found that the variant DT388IL3 ( $\triangle 125-133)$ showed an enhanced binding to the human IL3R and greater cytotoxicity to human AML cell lines and LSCs than the wild-type DT388IL3 [42]. Following the same way, our laboratory constructed and expressed the fusion protein antiCD3Fv-IL3 and discovered the fusion protein was unstable and could easily break in the end of the C-terminal (data not shown), which was also consistent with some combinatorial mutagenesis studies [22-25]. So we engineered the fusion protein antiCD3Fv- $\triangle \mathrm{IL} 3(\Delta 125-133)$ and its disulfide-stabilized antiCD3Fv- $\triangle \mathrm{IL} 3$, which combined the advantages of both the specificity of humoral immunity and the efficiency of cellular immunity compared with fusion proteins DT388IL3.

\section{Conclusion}

Fusion proteins antiCD3Fv- $\triangle \mathrm{IL} 3$ and disulfide-stabilized antiCD3Fv- $\triangle \mathrm{IL} 3$, especially the latter one, display the antileukemic activity against CD123-expressing cell lines as well as leukemic progenitors in vitro and in vivo. They could be the promising candidates for future immunotherapy of AML. In the future, we will explore various methods to enhance $\mathrm{T}$ lymphocyte activities against leukemic cells of AML, such as in combination with chemotherapeutics [43] or developing a multi-epitope reagent with ligands of costimulatory molecules.

\section{Methods and material Cell lines}

Hybridoma cell lines producing the antiCD3 monoclonal antibody HIT3a (IgG2a, к) were established and maintained at the Institute of Hematology, Chinese Academy of Medical Sciences (Tianjin, China) as described previously [44]. The human acute $\mathrm{T}$ cell leukemia cell line Jurkat, human acute myelogenous leukemia progenitor cell line KG1a, human acute monocytic cell line THP1, and human acute promyelocytic leukemia cell line NB4 were all derived from our laboratory. Jurkat, THP1, and NB4 were maintained in RPMI 1640 and KG1a in IMDM media (Gibco, Grand Island, NY) containing 10\% fetal bovine serum (Gibco, Grand Island, NY). All the cells were cultured at $37^{\circ} \mathrm{C}$ with $5 \% \mathrm{CO}_{2}$.

\section{Construction of plasmids of the antiCD3Fv- $\triangle \mathrm{IL} 3$ or disulfide-stabilized antiCD3Fv- $\triangle \mathrm{IL} 3$}

The fragments of antiCD3 $\mathrm{V}_{\mathrm{L}}$ and antiCD3* $\mathrm{V}_{\mathrm{L}}$ (containing a cysteines at position Ser-100 of CD3 $\mathrm{V}_{\mathrm{L}}$ ) containing the restriction enzyme site $\mathrm{MluI}$ and the G4S linker were obtained by polymerase chain reaction (PCR) from the plasmid pLH-T3a-19a and pLH-T3a"-19a [32], using the primer pairs P1/P2 (Table 1, all primers were synthesized by Invitrogen Life Technologies, USA), respectively. The antiCD3 $\mathrm{V}_{\mathrm{H}}$ and antiCD3* $\mathrm{V}_{\mathrm{H}}$ (containing a cysteines at position Gly-44 of $\mathrm{CD}_{3} \mathrm{~V}_{\mathrm{H}}$ ) segments containing the restriction enzyme site MluI and the G4S linker were generated similarly by PCR from the plasmid pLH-19a-T3a and pLH-19a-T3a* [32], respectively, using the primer pairs P5/P6. The fragment of $\triangle \mathrm{IL} 3$ (the end of eight amino acids were deleted) was obtained by PCR from cDNA of human peripheral blood mononuclear cells, using the primer pairs $\mathrm{P} 3 / \mathrm{P} 4$ (including the restriction enzyme site NheI and the G4S linker) or P3/P7 (both containing the G4S linker). The His tag and the restriction enzyme site SphI were introduced into the PCR products by re-amplification with the primer pairs 


$\begin{aligned} & \text { Table } \mathbf{1} \text { Primers used for construction of fusion proteins } \\
& \text { expression vectors }\end{aligned}$
\begin{tabular}{ll}
\hline $\begin{array}{l}\text { Primer } \\
\text { names }\end{array}$ & Primer sequence $\left(\mathbf{5}^{\prime} \boldsymbol{\rightarrow} \mathbf{3}^{\prime}\right)$ \\
\hline$P_{1}$ & CTTCGAGCTAGCTACCCGGGGATCCTCTAGAG \\
$P_{2}$ & CACCCTCCGCCACCCCG \\
$P_{3}$ & GGTGGCGGAGGTCGGCTCCCATGACCCAGACAAC \\
$P_{4}$ & GCGCGCTAGCTCACTGTGAGCCTGCGCATTCTC \\
$P_{5}$ & GCGCACGCGTACGCTCAGGTGCAGCTGCAGCAGT \\
$P_{6}$ & CCCTCCGCCACCTGAGGAGACGGTGACCGTG \\
$P_{7}$ & TGATCCGCCTCCACCAAAGATCGCGAGGCTCAAAGT \\
$P_{8}$ & GCGCGCATGCTCAATGATGGTGATGGTATGTGATCCGCCTCCACC \\
\hline
\end{tabular}

P3/P8. Overlap PCR was used to generate the fragments of antiCD3 $\mathrm{V}_{\mathrm{L}}-\mathrm{G} 4 \mathrm{~S}-\triangle \mathrm{IL} 3$ or antiCD3* $\mathrm{V}_{\mathrm{L}}-\mathrm{G} 4 \mathrm{~S}-\triangle \mathrm{IL} 3$ and antiCD $3 \mathrm{~V}_{\mathrm{H}^{-}}$G4S- $\triangle \mathrm{IL} 3-\mathrm{His}$ or antiCD3* $\mathrm{V}_{\mathrm{H}^{-}}$G4S- $\triangle \mathrm{IL} 3-$ His through the complementary sequences of the G4S linker. The resulted fusion products were cleaved with the restriction enzymes MluI/NheI and MluI/SphI and subsequently cloned into the pLH-T3a-19a and pLH$19 \mathrm{a}-\mathrm{T} 3 \mathrm{a}$ vectors to generate plasmids $\mathrm{pLH}-\mathrm{CD}_{\mathrm{V}} \mathrm{L}$ or $\mathrm{CD}^{*} \mathrm{~V}_{\mathrm{L}}-\triangle \mathrm{IL} 3$ and $\mathrm{pLH}-\mathrm{CD} 3 \mathrm{~V}_{\mathrm{H}}$ or $\mathrm{CD}^{*} \mathrm{~V}_{\mathrm{H}^{-}} \Delta \mathrm{IL} 3-\mathrm{His}$. The latter vector has contained the restriction enzymes site NheI and the E. coli heat-stable enterotoxin II (stII) signal at the $5^{\prime}$ end of antiCD $3 \mathrm{~V}_{\mathrm{H}}$ or antiCD3* $\mathrm{V}_{\mathrm{H}^{-}} \triangle \mathrm{IL} 3-$ His. The abovementioned vectors were cleaved with the restriction enzymes $\mathrm{MluI} / \mathrm{NheI}$ and NheI/SphI, respectively, to generate two fragments of antiCD3 $\mathrm{V}_{\mathrm{L}}$ or antiCD3* $\mathrm{V}_{\mathrm{L}}-\triangle \mathrm{IL} 3$ and stII-antiCD3 $\mathrm{V}_{\mathrm{H}}$ or antiCD3* $\mathrm{V}_{\mathrm{H}^{-}}$ $\triangle \mathrm{IL} 3-\mathrm{His}$ and then subcloned into the MluI/SphI sites of the expression vector pCANTAB5E (GE healthcare, Little Chalfont, Buckinghamshire, UK).

\section{The expression and purification of fusion proteins}

The soluble fusion protein was extracted from $E$. coli strain 16C9 containing the expression plasmids and purified by methods described previously [31]. The purified fusion proteins were subjected to electrophoresis in $12 \%$ polyacrylamide gels and stained with Coomassie brilliant blue to confirm their purity, respectively. In addition, an identical gel was transferred onto a PDVF membrane and a Western blot analysis was performed using a mouse anti-His-tag antibody IgG (Tiangen Biotech, Beijing, China) and goat antimouse antibody IgG conjugated with horseradish peroxidase (Union Stem Cell \& Gene engineering, Tianjin, China). Purified fusion proteins were kept under a sterile condition and stored at $-80^{\circ} \mathrm{C}$.

\section{Flow cytometric analysis}

The CD123-positive cell line KG1a and the CD3-positive cell line Jurkat were employed for analysis of binding activity of the purified proteins by flow cytometry (FACS LSRII, Becton Dickinson Bioscience, San Jose, CA). Briefly, $1 \times 10^{6}$ cells in $100-\mu \mathrm{L}$ phosphatebuffered saline (PBS) were incubated with various fusion proteins $(20 \mu \mathrm{g} / \mathrm{mL})$ for $1 \mathrm{~h}$ at $4^{\circ} \mathrm{C}$. After being washed three times with cold PBS, the cells were incubated with $100-\mu \mathrm{L}$ anti-His antibody IgG at $10 \mu \mathrm{g} / \mathrm{mL}$ for $1 \mathrm{~h}$, followed by incubation with $20 \mu \mathrm{L}$ of FITClabeled rabbit antimouse antibody IgG (Institute of Hematology, Chinese Academy of Medical Sciences, Tianjin, China) for an additional $30 \mathrm{~min}$. The stained cells were washed and analyzed by flow cytometry. In a competitive binding assay, $1 \times 10^{6} \mathrm{KG} 1 \mathrm{a}$ cells in 100 $\mu \mathrm{L}$ PBS were first incubated with $20 \mu \mathrm{g} / \mathrm{mL}$ of various fusion proteins for $1 \mathrm{~h}$ at $4^{\circ} \mathrm{C}$, then incubated with parent McAb IgG (CD123 McAb for KG1a and HIT3a for Jurkat cells, respectively) for $1 \mathrm{~h}$ at $4^{\circ} \mathrm{C}$. After being washed three times with cold PBS, the cells were incubated with an FITC-conjugated rabbit antimouse IgG for $30 \mathrm{~min}$. The stained cells were then analyzed by flow cytometry.

\section{Stability assays in vitro}

Fusion proteins were incubated at a concentration of $20 \mu \mathrm{g} / \mathrm{mL}$ in PBS containing $0.2 \%(w / v) \mathrm{HSA}$ at $37^{\circ} \mathrm{C}$ for a variety of time periods. The remaining binding activity of the fusion proteins incubated with KG1a or Jurkat cells were detected using flow cytometry.

\section{Isolation of PBMC, sorting, and stimulation of T lymphocytes}

With informed consent obtained, human peripheral blood mononuclear cells (PBMCs) were isolated from peripheral blood taken from healthy volunteers or AML patients using Ficoll-Hypaque density-gradient centrifugation (Institute of Hematology, Chinese Academy of Medical Sciences, Tianjin, China). The clinical processes were approved by the Ethics Committees of the Hospital of Blood Disease, Peking Union Medical College. The mononuclear cell layer was removed, washed twice, and cell number counted, then the cell suspension was depleted of monocytes by adherence to plastic flasks for $2 \mathrm{~h}$. Non-adherent cells were used for $\mathrm{T}$ cell isolation by fluorescence-activated cell sorter (FACS). PBMCs $\left(1 \times 10^{8}\right)$ in $500-\mu \mathrm{L}$ PBS were incubated with $15 \mu \mathrm{L}$ of allophycocyanin (APC)-conjugated antihuman CD3 mAbs (clone UCHT1,BD Pharmingen, San Diego, $\mathrm{CA}$ ) at $4^{\circ} \mathrm{C}$ for $60 \mathrm{~min}$ and then washed twice with PBS. $\mathrm{T}$ cells sorted out by FACS (AriaIII, Becton Dickinson Biosciences) were cultured in a complete RPMI 1640 medium containing $10 \%$ FCS and $50 \mathrm{IU} / \mathrm{mL}$ of IL2 for $48 \mathrm{~h}$ to activate $\mathrm{T}$ lymphocytes. 


\section{Cytotoxicity assay in vitro}

The efficacy of fusion proteins in mediating $\mathrm{T}$ cell cytotoxicity was evaluated by the calcein-release assay [45]. The CD123-positive cell line KG1a and the CD123negative cell line THP1 and NB4 were prepared as target cells. Equal concentrations of antiCD3 $\times$ antiCD19 diabody were established as control. The experimental and calculating methods were proceeded as described previously [31].

\section{Methylcellulose colony-forming assay}

To evaluate inhibition of colony formation, the mononuclear cells from peripheral blood of an AML patient were cultured in serum-free IMDM for $24 \mathrm{~h}$ in the presence or absence of different fusion proteins $(500 \mathrm{ng} / \mathrm{mL})$ combined with pre-activated $\mathrm{T}$ cells at the effector-target cell ratio of 3:1. Then, cells were plated in 96-well plates at 10,000 cells $/ 25 \mu \mathrm{L}$ or 40,000 cells $/ 25 \mu \mathrm{L}$ in Methocult $\mathrm{H} 4434$. And the numbers of colonies were scored after 15-20 days of culture. All the treatments were performed in triplicate.

\section{Growth inhibition of human KG1a xenografts in vivo}

All animal procedures were approved by Ethics Committee on the use and care of animals, Chinese Academy of Medical Science. Female 6-week-old NOD/SCID mice (Cancer Institute, Chinese Academy of Medical Sciences, Beijing, China) were inoculated subcutaneously with $2 \times 10^{7} \mathrm{KG} 1$ a cells into armpits, 1 day after the application of total body irradiation (300 cGy). Treatment was initiated at 6 days post-tumor inoculation, when the solid tumors reached $80-100 \mathrm{~mm}^{3}$ in size. Each group consisted of seven mice at least. Mice were treated with two different doses (50, $100 \mu \mathrm{g} /$ mouse) of the two fusion proteins, combined with preactivated T cells $\left(5 \times 10^{6}\right.$ cells/mouse $)$ in PBS via the tail vein, every 7 days for 2 weeks. Mice received intravenous injections of various fusion proteins $(100 \mu \mathrm{g} /$ mouse $)$ alone, pre-activated T cells $\left(5 \times 10^{6}\right.$ cells/mouse $)$, a combination of antiCD $3 \times$ antiCD19 $(100 \mu \mathrm{g} / \mathrm{mouse})$ diabody and pre-activated T cells $\left(5 \times 10^{6}\right.$ cells/mouse), or PBS as control. Growing tumors were measured using a vernier caliper in two perpendicular dimensions every 3 days, and the tumor volumes were calculated using the following formula: $V=\left(L \times W^{2}\right) / 2$, where $L$ represents the longest axis of the tumors (in $\mathrm{mm}$ ) and $W$ represents the axis perpendicular to $L$ (in $\mathrm{mm}$ ). Mice were sacrificed by cervical dislocation under anesthesia when the tumors reached $4,000 \mathrm{~mm}^{3}$ in size. The mean tumor volume of the treatment groups and control groups were evaluated by Student's $t$-test with SPSS18.0 software (SPSS, Cary, NC).

\section{Additional files}

Additional file 1: Movie 1. The process of cytotoxicity of IL2 pre-activated of human T cells to KG1a cells mediated by the fusion protein antiCD3Fv- $\Delta \mathrm{IL} 3$ was observed by Nikon Ti-e cell-imaging system. Cells $\left(5 \times 10^{3} \mathrm{KG} 1 \mathrm{a}\right.$ per well) were plated in a 96-well plate, followed by added IL2 pre-activated human T cells at effector-target cell ratio of 25:1 in the presence of antiCD3Fv- $\Delta \mathrm{L}$ 3 ( $500 \mathrm{ng} / \mathrm{mL}$ ). After a transient laid aside in the incubator, the plate was observed by Nikon Ti-e cell-imaging system. Several fields were chosen and a picture was taken for each every $1 \mathrm{~h}$. The actual speed of the movie plays at roughly 500 ms/frame. In the movie, the larger cells were KG1a cells and the smaller cells were T cells. The process of recruitment of $T$ cell to tumor cells and the lysis of tumor cells was observed.

Additional file 2: Movie 2. The process of cytotoxicity of IL2 pre-activated of human $T$ cells to KG1a cells mediated by the fusion protein ds-antiCD3Fv- $\triangle \|$ L3 was observed by Nikon Ti-e cell-imaging system. The same as antiCD3Fv- $\Delta \| \mathrm{L} 3$, we can observe the process of recruitment of T cell to tumor cells and the lysis of tumor cells in this movie. The larger cells were KG1a cells and the smaller cells were $T$ cells.

Additional file 3: Figure S1. The typical screenshots of movie 1 ( $A, B$, C, D) displayed the cytotoxicity of T cells mediated by the fusion protein antiCD3Fv- $\Delta \mathrm{I}$ 3 3 in one field at different time points. The blue areas showed the typical process of cytotoxicity. The larger cells were KG1a cells and the smaller cells were T cells. The fusion protein antiCD3Fv- $\Delta \mathrm{IL} 3$ appeared to be potent in retargeting $\mathrm{T}$ cell lysis of the KG1a cells.

Additional file 4: Figure S2. The typical screenshots of movie 2 (A, B, C, D) displayed the cytotoxicity of $T$ cells mediated by the fusion protein ds-antiCD3Fv- $\Delta \mathrm{I} 33$ in one field at different time points. The blue areas showed the typical process of cytotoxicity. The same as antiCD3Fv- $\Delta \mathrm{L}$ 3, ds-antiCD3Fv- $\Delta \mathrm{IL} 3$ also appeared to be potent in retargeting $T$ cell lysis of the KG1a cells.

\section{Abbreviations}

AML: Acute myeloid leukemia; CAR: Chimeric antigen receptor;

CFCs: Colony-forming cells; CTL: Cytotoxic T lymphocyte; ds: Disulfide-stabilized; IL3: Interleukin-3; LSCs: Leukemic stem cells; MRD: Minimal residual disease; MHC: Major histocompatibility complex; NOD/SCID: Non-obese diabetic/severe combined immunodeficient; PBMC: Peripheral blood mononuclear cells; PCR: Polymerase chain reaction; scFv: Single-chain Fv.

\section{Competing interests}

The authors declare that they have no competing interests.

\section{Authors' contributions}

DF contributed to the cytotoxicity assay in vitro and in vivo, and the joint first author ZL constructed the plasmids of antiCD3Fv- $\Delta \mathrm{L} 3$ and ds-antiCD3Fv- $\Delta \mathrm{IL} 3$ and completed the expression and purification of these two fusion proteins. YY isolated T lymphocytes from PBMC. XOZ finished the binding assay of the fusion proteins. $X Y$ contributed to the stability assay in vitro. $X Z$ was responsible for the culture of cells in this study. MY and YZ collected the clinical samples. DX was the corresponding author and contributed to the design of this subject. All authors read and approved the final manuscript.

\section{Authors' information}

Dongmei Fan and Zhenzhen Li are joint first authors.

\section{Acknowledgements}

This work was supported by grants from the Natural Science Foundation of China (Grant No. 30873091 and 30971291), Natural Science Foundation of Tianjin (Grant No.05YFZGX02800), and National Science and Technology Major Project (Grant No.2009ZX09103-720), Peking Union Medical Colleges Graduate innovation Fund Project (Grant No. 2012-1007-009).

\section{Author details}

${ }^{1}$ State Key Laboratory of Experimental Hematology, Institute of Hematology \& Hospital of Blood Diseases, Chinese Academy of Medical Sciences and Peking Union Medical College, Tianjin 300020, People's Republic of China. ${ }^{2}$ School of Pharmacy, Tianjin Medical University, Tianjin 300070, People's 
Republic of China. ${ }^{3}$ Central Hospital of Karamay, Karamay, Xinjiang 834000, China.

Received: 2 October 2014 Accepted: 13 January 2015 Published online: 28 February 2015

\section{References}

1. Eaves CJ, Humphries RK. Acute myeloid leukemia and the Wht pathway. N Engl J Med. 2010;362:2326-7.

2. Döhner H, Estey EH, Amadori S, Appelbaum FR, Büchner T, Burnett AK, et al. Diagnosis and management of acute myeloid leukemia in adults: recommendations from an international expert panel, on behalf of the European LeukemiaNet. Blood. 2010;115:453-74.

3. List AF. Role of multidrug resistance and its pharmacological modulation in acute myeloid leukemia. Leukemia. 1996;10:937-42.

4. Bonnet D, Dick JE. Human acute myeloid leukemia is organized as a hierarchy that originates from a primitive hematopoietic cell. Nat Med. 1997:3:730-7.

5. Fuchs D, Daniel V, Sadeghi M, Opelz G, Naujokat C. Salinomycin overcomes $\mathrm{ABC}$ transporter-mediated multidrug and apoptosis resistance in human leukemia stem cell-like KG-1a cells. Biochem Biophys Res Commun. 2010;394:1098-104.

6. Ali MA, Naka K, Yoshida A, Fuse K, Kasada A, Hoshii T, et al. Association of a murine leukaemia stem cell gene signature based on nucleostemin promoter activity with prognosis of acute myeloid leukaemia in patients. Biochem Biophys Res Commun. 2014:450:837-43.

7. Majeti R. Monoclonal antibody therapy directed against human acute myeloid leukemia stem cell. Oncogene. 2011;30:1009-19.

8. Testa U, Riccioni R, Diverio D, Rossini A, Lo Coco F, Peschle C. Interleukin-3 receptor in acute leukemia. Leukemia. 2004;18:219-26.

9. Jin L, Lee EM, Ramshaw HS, Busfield SJ, Peoppl AG, Wilkinson L, et al. Monoclonal antibody-mediated targeting of CD123, IL-3 receptor alpha chain, eliminates human acute myeloid leukemic stem cells. Cell Stem Cell. 2009;5:31-42.

10. Frankel AE, McCubrey JA, Miller MS, Delatte S, Ramage J, Kiser M, et al. Diphtheria toxin fused to human interleukin-3 is toxic to blasts from patients with myeloid leukemias. Leukemia. 2000;14:576-85.

11. Feuring-Buske M, Frankel AE, Alexander RL, Gerhard B, Hogge DE. A diphtheria toxin-interleukin 3 fusion protein is cytotoxic to primitive acute myeloid leukemia progenitors but spares normal progenitors. Cancer Res. 2002;62:1730-6.

12. Gajewski TF, Schumacher T. Cancer immunotherapy. Curr Opin Immunol. 2013;25:259-60.

13. Rinaldi M, Fioretti D, lurescia S, Signori E, Pierimarchi P, Seripa D, et al. Anti-tumo immunity induced by CDR3-based DNA vaccination in a murine B-cell lymphoma model. Biochem Biophys Res Commun. 2008;370:279-84.

14. Stinchcombe JC, Bossi G, Booth S, Griffiths GM. The immunological synapse of CTL contains a secretory domain and membrane bridges. Immunity. 2001;15:751-61.

15. Shekhar C. Double whammy: bispecific antibodies help immune cells attack tumors. Chem Biol. 2008;15:877-8.

16. Satta A, Mezzanzanica D, Turatti F, Canevari S, Figini M. Redirection of T-cell effector functions for cancer therapy: bispecific antibodies and chimeric antigen receptors. Future Oncol. 2013;9:527-39.

17. Kuo SR, Wong L, Liu JS. Engineering a CD123xCD3 bispecific scFv immunofusion for the treatment of leukemia and elimination of leukemia stem cells. Protein Eng Des Sel. 2012;25:561-9.

18. Mardiros A, Dos Santos C, McDonald T, Brown CE, Wang X, Budde LE, et al. T cells expressing CD123-specific chimeric antigen receptors exhibit specific cytolytic effector functions and antitumor effects against human acute myeloid leukemia. Blood. 2013;122:3138-48.

19. Tettamanti S, Marin V, Pizzitola I, Magnani CF, Giordano Attianese GM, Cribioli E, et al. Targeting of acute myeloid leukemia by cytokine-induced killer cells redirected with a novel CD123-specific chimeric antigen receptor. Br J Haematol. 2013;161:389-401.

20. Nitsche A, Junghahn I, Thulke S, Aumann J, Radonić A, Fichtner I, et al. Interleukin-3 promotes proliferation and differentiation of human hematopoietic stem cells but reduces their repopulation potential in NOD/SCID mice. Stem Cells. 2003;21:236-44.

21. Chang F, Steelman LS, Lee JT, Shelton JG, Navolanic PM, Blalock WL, et al. Signal transduction mediated by the Ras/Raf/MEK/ERK pathway from cytokine receptors to transcription factors: potential targeting for therapeutic intervention. Leukemia. 2003:17:1263-93.

22. Lopez AF, Shannon MF, Barry S, Phillips JA, Cambareri B, Dottore M, et al. A human interleukin 3 analog with increased biological and binding activities. Proc Natl Acad Sci U S A. 1992;89:11842-6.

23. Klein BK, Olins PO, Bauer SC, Caparon MH, Easton AM, Braford SR, et al. Use of combinatorial mutagenesis to select for multiply substituted human interleukin-3 variants with improved pharmacologic properties. Exp Hematol. 1999;27:1746-56

24. Klein BK, Feng Y, McWherter CA, Hood WF, Paik K, McKearn JP. The receptor binding site of human interleukin-3 defined by mutagenesis and molecular modeling. J Biol Chem. 1997;272:22630-41.

25. Liu TF, Urieto JO, Moore JE, Miller MS, Lowe AC, Thorburn A, et al. Diphtheria toxin fused to variant interleukin-3 provides enhanced binding to the interleukin-3 receptor and more potent leukemia cell cytotoxicity. Exp Hematol. 2004;32:277-81.

26. Kadowaki N, Kitawaki T. Recent advance in antigen-specific immunotherapy for acute myeloid leukemia. Clin Dev Immunol. 2011;2011:104926.

27. Kikushige Y, Shima T, Takayanagi S, Urata S, Miyamoto T, Iwasaki H, et al. TIM-3 is a promising target to selectively kill acute myeloid leukemia stem cells. Cell Stem Cell. 2010;7:708-17.

28. Muñoz L, Nomdedéu JF, López O, Carnicer MJ, Bellido M, Aventín A, et al. Interleukin-3 receptor alpha chain (CD123) is widely expressed in hematologic malignancies. Haematologica. 2001;86:1261-9.

29. Testa U, Riccioni R, Militi S, Coccia E, Stellacci E, Samoggia P, et al. Elevated expression of IL-3R alpha in acute myelogenous leukemia is associated with enhanced blast proliferation, increased cellularity, and poor prognosis. Blood. 2002:100:2980-8.

30. Du W, Li XE, Sipple J, Pang Q. Overexpression of IL-3Ra on CD34 + CD38- stem cells defines leukemia- initiating cells in Fanconi anemia AML. Blood. 2011;117:4243-52.

31. Liu J, Yang $M$, Wang J, $X u Y$, , Wang $Y$, Shao $X$, et al. Improvement of tumor targeting and antitumor activity by a disulphide bond stabilized diabody expressed in Escherichia coli. Cancer Immunol Immunother. 2009:58:1761-9.

32. Wei L, Dongmei F, Ming Y, Ruizan S, Yan Y, Linlin J, et al. Disulfide-stabilized diabody antiCD19/antiCD3 exceeds its parental antibody in tumor-targeting activity. Cell Oncol (Dordr). 2012;35:423-34.

33. Roug AS, Larsen $H \varnothing$, Nederby L, Just T, Brown G, Nyvold CG, et al. hMICL and CD123 in combination with a CD45/CD34/CD117 backbone - a universal marker combination for the detection of minimal residual disease in acute myeloid leukaemia. Br J Haematol. 2014;164:212-22.

34. Brossart $P$, Schneider A, Dill P, Schammann T, Grünebach F, Wirths $S$, et al. The epithelial tumor antigen MUC1 is expressed in hematological malignancies and is recognized by MUC1-specific cytotoxic T-lymphocytes. Cancer Res. 2001:61:6846-50.

35. Majeti R, Chao MP, Alizadeh AA, Pang WW, Jaiswal S, Gibbs Jr KD, et al CD47 is an adverse prognostic factor and therapeutics antibody target on human acute myeloid leukemia stem cells. Cell. 2009;138:286-99.

36. Golden-Mason L, Palmer BE, Kassam N, Townshend-Bulson L, Livingston S, McMahon BJ, et al. Negative immune regulator Tim-3 is overexpressed on T cells in hepatitis $C$ virus infection and its blockade rescues dysfunctional CD4+ and CD8+ T cells. J Virol. 2009;83:9122-30.

37. Steer HJ, Lake RA, Nowak AK, Robinson BW. Harnessing the immune response to treat cancer. Oncogene. 2010;29:6301-13.

38. Louis CU, Savoldo B, Dotti G, Pule M, Yvon E, Myers GD, et al. Antitumor activity and long-term fate of chimeric antigen receptor-positive T cells in patients with neuroblastoma. Blood. 2011;118:6050-6.

39. Brentjens RJ, Rivière I, Park JH, Davila ML, Wang X, Stefanski J, et al. Safety and persistence of adoptively transferred autologous CD19-targeted T cells in patients with relapsed or chemotherapy refractory B-cell leukemias. Blood. 2011;118:4817-28

40. Morgan RA, Yang JC, Kitano M, Dudley ME, Laurencot CM, Rosenberg SA Case report of a serious adverse event following the administration of $T$ cells transduced with a chimeric antigen receptor recognizing ERBB. Mol Ther. 2010;18:843-51

41. Klinger M, Brandl C, Zugmaier G, Hijazi Y, Bargou RC, Topp MS, et al. Immunopharmacologic response of patients with B-lineage acute lymphoblastic leukemia to continuous infusion of T cell-engaging CD19/CD3-bispecific BiTE antibody blinatumomab. Blood. 2012;119:6226-33.

42. Hogge DE, Yalcintepe L, Wong SH, Gerhard B, Frankel AE. Variant diphtheria toxin-interleukin-3 fusion proteins with increased receptor affinity have 
enhanced cytotoxicity against acute myeloid leukemia progenitors. Clin Cancer Res. 2006;12:1284-91.

43. Vereecque R, Saudemout A, Quesnel B. Cytosine arabinoside induces costimulatory molecule expression in acute myeloid leukemia cells. Leukemia. 2004;18:1223-30.

44. Shen D. A high affinity CD3 monoclonal antibody HIT3a. Zhongguo Yi Xue Ke Xue Yuan Xue Bao. 1993;15:157-62.

45. Schlereth B, Quadt C, Dreier T, Kufer P, Lorenczewski G, Prang N, et al. T-cell activation and B-cell depletion in chimpanzees treated with a bispecific anti-CD19/anti-CD3 single-chain antibody construct. Cancer Immunol Immunother. 2006;55:503-14.

\section{Submit your next manuscript to BioMed Central} and take full advantage of:

- Convenient online submission

- Thorough peer review

- No space constraints or color figure charges

- Immediate publication on acceptance

- Inclusion in PubMed, CAS, Scopus and Google Scholar

- Research which is freely available for redistribution 